\title{
Ash-free indigestible acid detergent fiber as an internal marker to estimate digestibility with grazing ruminants
}

\author{
M.L. NELSON, L. MOTJOPE, J.W. FINLEY, AND S.M. PARISH
}

\section{Abstract}

Two experiments with wethers and one with steers were conducted to compare extraction methods of ash-free indigestible acid detergent fiber (IADF) from feed, and to determine variation across days in fecal IADF content. In trial 1, 4 wethers were fed 4 maturities of intermediate wheatgrass (Agropyron intermedium) in a $4 \times 4$ Latin square digestion trial. Methods of IADF extraction from feed were analytically defined as the ash-free acid detergent fiber residue remaining after: (1) 48-hour ruminal-fluid-buffer incubation, 24-hour pepsin-HCl hydrolysis, then a 96-hour in vitro incubation; (2) pepsin- $\mathrm{HCl}$ digestion then a 96-hour in vitro incubation; and (3) 96-hour in vitro incubation. Method of IADF extraction and fecal IADF recovery were not affected by, and did not interact $(P>.1)$ with wheatgrass maturity. Fecal IADF recovery averaged $96.6,80.6$, and 77.2\% for extraction Methods 1,2 , and 3 , respectively, and Method 1 differed from Method $2(P<1$ and 3 $(P<.05)$. Four steers were fed 6 maturities of fresh bromegrass in a repeated measures design with a factorial arrangement in the subplot. Main effects were method of IADF extraction (1, 2, or 3) and endpoint of the incubation $(96$ or $120 \mathrm{~h}$ ). No main effect of endpoint was detected. Method 1 differed $(P<.01)$ from Method 3, but not Method 2, in forage IADF content and fecal recovery of IADF. Organic matter digestibility determined by total collection differed $(P<.01)$ from that calculated from feed to feces ratio using IADF extracted by Method 3, but not by Methods 1 and 2 . In a graxing trial, fecal IADF content varied little among sampling days within a period. Ash-free IADF extracted from feed by Method 1 appeared to be a suitable internal marker to calculate digestibility by forage-fed or grazing ruminants.

Key Words: internal marker, forage, digestibility, steers, wethers

Ideal internal markers (Faichney 1975) would be useful to estimate digestibility from feed:feces ratios (Schneider and Flatt 1975) and to estimate voluntary intake from fecal output. An ideal marker according to Faichney (1975) is: (1) nonabsorbable, (2) not affected by and does not affect the gastrointestinal tract or its microbes, (3) physically similar to or intimately associated with the digesta fraction to be marked, and (4) estimated by an analysis that is specific, sensitive, and does not interfere with other analyses. However, most internal markers are not ideal (Streeter 1969, Scales et al. 1974).

Theoretically, lignin should function as an ideal internal marker; but lack of quantitative recovery of lignin, isolated by standard methods, has been reported (Kotb and Luckey 1972, Fahey and Jung 1983), which violates the criteria of an ideal marker. An alternative internal marker is indigestible fiber.

Berger et al. (1979) and Waller et al. (1980) stated that indigestible acid detergent fiber (IADF) has the characteristics of an ideal marker. However, many procedures have been used to extract IADF from feed samples (Berger et al. 1979, Waller et al. 1980,

\footnotetext{
Authors are associate professor and former graduate research assistants, Department of Animal Sciences; and associate professor, College of Veterinary Medicine, Washington State University, Pullman 99164. The authors gratefully acknowledge two anonymous reviewers for their careful reviews and constructive criticisms of this manuscript.

Scientific Paper No. 7882, College of Agriculture and Home Economics, Washington State University. Research conducted under Project No. 0713.

Manuscript accepted 31 August 1989.
}

Penning and Johnson 1983, Ellis et al. 1984, Hunt et al. 1984, Cochran et al. 1986). In general, most IADF extraction procedures appeared appropriate for ruminants fed mature forages. However, Cochran et al. (1986) noted that IADF recovery in feces was low for steers fed immature tall fescue ( $82 \%$ in vivo dry matter digestibility), presumably because of overestimation of IADF content of feed. However, Penning and Johnson (1983) suggested that fecal IADF (cellulase indigestible) was overestimated in sheep fed immature ryegrass ( $84 \%$ in vivo dry matter digestibility). These data indicate variability in current procedures and the need for appropriate methodology for extraction of IADF. Therefore, the objectives of these experiments were to compare IADF extraction methods across stage of maturity of wilted and fresh forage; determine components of variance associated with animal, period of grazing, and day within period to estimate the number of fecal grab samples needed to adequately estimate fecal IADF content; and compare organic matter digestibility estimates calculated using IADF and in vitro indigestibility. These data are needed to identify appropriate methodology for use of IADF as an internal marker to estimate organic matter digestibility with grazing ruminants.

\section{Materials and Methods}

\section{Wether Digestion Trial}

Intermediate wheatgrass (Agropyron intermedium) was harvested at 4 stages of maturity at 21-day intervals from 26 May to 6 Aug. 1985. The physiological stages of forage maturity at harvest were late boot, fullhead, mature, and post ripe for maturity $1,2,3$, and 4 , respectively. Forage was cut with a rotary mower and sun-cured to about $85 \%$ dry matter (DM).

Four wethers $(82 \mathrm{~kg})$ were allotted randomly to a $4 \times 4$ Latin square design. Dietary treatments were the 4 stages of intermediate wheatgrass maturity. Two cells of the earliest maturity forage were missing due to a lack of forage. Wethers were fed, in amounts to allow $20 \%$ feed refusals (orts), twice daily at 0700 and 1900 . Water and mineral supplement (50\% dicalcium phosphate and $50 \%$ trace mineral salt ${ }^{1}$ ) were provided ad libitum.

Wethers were housed in a temperature controlled $\left(21^{\circ} \mathrm{C}\right)$, continuously lighted environment. Periods were 11 days in duration, which included days 1 to 7 for diet adaptation and days 8 to 11 for total fecal collection. Feed intake was determined as feed offered corrected for orts from day 6 to 9.

Daily aliquots of feed, orts, and feces were oven dried at $50^{\circ} \mathrm{C}$, ground to pass a $1-\mathrm{mm}$ screen in a Wiley Mill, and composited by wether within period. Chemical analyses of forage, orts, and feces included crude protein (CP) by macro-Kjeldahl (AOAC 1980) and neutral detergent fiber (NDF), acid detergent fiber (ADF), and acid detergent lignin (ADL) according to Goering and Van Soest (1970). In vitro organic matter digestibility (IVOMD) was determined by the Moore modification (Harris 1970) of Tilley and Terry (1963) with ruminal fluid collected from 2 bromegrass fed cows and ash by ignition at $600^{\circ} \mathrm{C}$ for $6 \mathrm{~h}$.

Ash-free indigestible acid detergent fiber (IADF) content of feed

$197 \% \mathrm{NaCl}, .002 \% \mathrm{Se}, .005 \% \mathrm{Co}, .007 \% \mathrm{I}, .03 \% \mathrm{Cu}, .02 \% \mathrm{Fe}, .2 \% \mathrm{Mn}, .15 \% \mathrm{Mg}, .035 \%$ $\mathrm{Zn}$. 
and orts was analytically defined as the ash-free ADF remaining after: (1) in vitro digestion (48-hour ruminal fluid-buffer incubation plus a 24-hour pepsin-HCl incubation) using the Moore modification (Harris 1970) of Tilley and Terry (1963), adjustment to $\mathrm{pH}$ 7.0 with $\mathrm{Na}_{2} \mathrm{CO}_{3}$ then incubation with ruminal fluid-McDougall's buffer mixture for 96 hours (Nelson et al. 1985); (2) 24-hour HCl (6 $\mathrm{ml} 20 \% \mathrm{HCl}$-pepsin ( $2 \mathrm{ml} \mathrm{5 \%}$ pepsin) hydrolysis, adjustment to $\mathrm{pH}$ 7.0 with $\mathrm{Na}_{2} \mathrm{CO}_{3}$, then incubation with ruminal fluid-McDougall's buffer mixture for 96 hours (modified from Berger et al. 1979 and Waller et al. 1980); and (3) incubation with ruminal fluid-McDougall's buffer mixture for 96 hours (Hunt et al. 1984). Method 1 was previously used by Nelson et al. (1985) as it mimics the previous digestion of abomasal contents or feces through the gastrointestinal tract. Method 2 would simulate the acid-pepsin conditions the digesta would be exposed to in the abomasum. A 96-hour incubation was selected because Mertens (1976) used this incubation time to determine indigestibility of NDF and ADF. Fecal IADF was analytically defined as the ash-free ADF remaining after a 96-hour incubation with ruminal fluid-McDougall's buffer mixture. Pretreatment of fecal samples with either an in vitro digest or $\mathrm{HCl}$ pepsin was deemed unnecessary because of previous in vivo exposure to these conditions.

All incubations were conducted in duplicate in $100 \mathrm{ml}$ centrifuge tubes sealed with rubber stoppers fitted with gas release valves. Samples (about $.5 \mathrm{~g}$ ) were prewetted with $2 \mathrm{ml}$ distilled water $\left(100^{\circ}\right.$ C) and incubated $\left(39^{\circ} \mathrm{C}\right)$ in $40 \mathrm{ml}$ of a 1:4 mixture of strained ruminal fluid collected from 2 bromegrass hay-fed cows fitted with rumen fistulas, and buffer (McDougall 1948) with $1 \mathrm{~g}$ urea/liter added. Incubations were arrested by the addition of $1 \mathrm{ml}$ saturated $\mathrm{Hg}_{2} \mathrm{Cl}_{2}$. Tube contents were quantitatively transferred to $600-\mathrm{ml}$ berzelius beakers, $100 \mathrm{ml}$ of acid detergent solution was added, refluxed for 60 min following initiation of boiling, and filtered through tared Whatman No. 541 filter paper.

Data were analyzed by analysis of variance for a $4 \times 4$ Latin square with effects of method of IADF extraction and the method of IADF extraction by wheatgrass maturity interaction added as subplot effects to the model. Main plot effects of wheatgrass maturity, sheep and period were tested using the appropriate error term for a $4 \times 4$ Latin square. Due to the 2 missing cells, the main plot error term had 2 less degrees of freedom than a complete $4 \times 4$ Latin square would have. Method of IADF extraction and its interaction with wheatgrass maturity were tested using residual error. Preplanned contrasts were calculated for Method 1 vs Method 2 and Method 1 vs Method 3 (Steel and Torrie 1980).

\section{Steer Digestion Trial}

Fresh bromegrass (Bromus inermis) was harvested at 6 stages of maturity at 21-day intervals from 5 May to 18 Aug. 1987. The physiological stages of forage maturity at harvest were 4 leaf to early boot, late boot to early head, middle head, full head, and 2 postripe stages for maturity $1,2,3,4,5$, and 6 , respectively. Bromegrass was swathed into windrows, hand collected into $210 \mathrm{~L}$ double lined plastic bags, and stored $\left(0^{\circ} \mathrm{C}\right)$ without wilting or fermentation until fed.

Four crossbred steers $(425 \mathrm{~kg}$ ) fitted with esophageal fistulas were fed each maturity of bromegrass in a repeated measures design (Gill and Hafs 1971). Steers were housed in individual $2 \times 4 \mathrm{~m}$ pens in an environmentally controlled room $\left(21^{\circ} \mathrm{C}\right)$ with continuous access to water and trace mineralized salt ${ }^{1}$. Steers were fed at 0800 in amounts to allow $30 \%$ feed refusals (orts) on a dry matter basis. Each period consisted of 12 days: days 1 to 8 for adaptation to ad libitum intake and days 9 to 12 for total fecal collection. Dry matter intake was calculated as feed offered, corrected for orts, from days 7 to 10 .

Feed and orts samples were freeze-ground with dry ice to pass a $1-m m$ screen in a Wiley Mill and feces were oven dried $\left(50^{\circ} \mathrm{C}\right)$ and ground through a $1-\mathrm{mm}$ screen in a Wiley Mill. Chemical analyses of forage, orts, and feces used methods described previously. Ashfree indigestible acid detergent fiber content of feed and orts were analytically defined as Methods 1, 2, and 3 of the wether digestion trial with 96 and 120 hours for the final incubation in ruminal fluid-buffer. Organic matter digestibility was calculated from total fecal collection and the feed to feces ratio of IADF (Schneider and Flatt 1975).

Data were analyzed by analysis of variance for a repeated measures design with a factorial arrangement for IADF extraction method added as subplot effects to the model. Main effects in the subplot were method of IADF extraction (Methods 1, 2 and 3 as described for the wether digestion trial) and endpoint of the in vitro fermentation (96 or 126 hours). Main plot effects of bromegrass maturity and steer were tested using the bromegrass maturity by steer interaction. Orthogonal contrasts were calculated for linear, quadratic and cubic effects of bromegrass maturity. Method of IADF extraction, endpoint of the in vitro fermentation and their interaction, and the interactions of bromegrass maturity with Method of IADF extraction and endpoint of the in vitro fermentation were tested using bromegrass maturity by method of IADF extraction by endpoint of the in vitro fermentation as the error term. Preplanned contrasts for feed IADF content were Method 1 vs Method 2 and Method 1 vs Method 3. Organic matter digestibility data were analyzed as a repeated measures design with a $2 \times 2+$ 1 factorial arrangement of treatments. Main effects were as previously described with total collection as the added treatment. The pre-planned contrasts for organic matter digestibility were total fecal collection vs Method 1 feed to feces IADF ratio, total fecal collection vs Method 2 feed to feces IADF ratio, and total fecal collection vs Method 3 feed to feces IADF ratio (Steel and Torrie 1980).

\section{Graxing Trial}

Four wethers about 6 weeks of age (avg. wt. $30.9 \mathrm{~kg}$ ) were surgically fitted with esophageal fistulas. The grazing trial commenced on 5 June and ended on 27 Aug. 1985. After a 19-day initial adjustment period on the pasture, wethers were assigned to 16-day periods which consisted of 11 days pre-conditioning and 5 days of sample collection. Additionally, 18 wethers (avg. wt. $25.2 \mathrm{~kg}$ ) grazed the pasture to reduce forage standing crop and forage quality so the measurements could be made with forages of different quantities and qualities. The .5-ha pasture used for grazing contained a mixture of downy brome (Bromus tectorum L.), foxtail barley (Hordium jubatum L.), hairy brome (Bromus commutas Schrad.), hardgrass (Schlerochloa dura (L.) Beauv.), Kentucky bluegrass (Poa pratensis L.), quackgrass (Agropyron repens L.), and orchardgrass (Dactylis glomerata L.). Water and trace mineralized salt ${ }^{1}$ were available ad libitum.

On day 11 of each period, the 4 fistulated wethers were fitted with fecal bags. Fecal grab samples were collected from the 4 fistulated wethers every 12 hours across the 5-day collection period. Fecal grab samples were oven dried $\left(50^{\circ} \mathrm{C}\right)$, ground to pass a 1-mm screen in a Wiley Mill, and the 2 samples within a day for a wether were composited on an equal DM basis $(w / w)$. Total feces were collected daily for 5 days, weighed, and a $10 \%$ aliquot was frozen $\left(-40^{\circ} \mathrm{C}\right)$. At the end of a collection period, aliquots were oven dried $\left(50^{\circ} \mathrm{C}\right)$, ground through a $1-\mathrm{mm}$ screen in a Wiley Mill, and composited $(w / w)$ by wether within period. Composite samples were frozen $\left(-40^{\circ} \mathrm{C}\right)$ until subsequent analyses. Total fecal output was corrected to include the dry weight of the 10 fecal grab samples.

Esophageal samples were collected daily in each collection period, without prior fasting, during morning and afternoon peri- 
Table 1. Effect of extraction method on indigestible scid detergent fiber content in feed, fecal recovery and organic matter digestibility measured by total fecal collection and feedfeces ratios for wethers.

\begin{tabular}{|c|c|c|c|c|}
\hline \multirow[b]{2}{*}{ Item } & \multirow{2}{*}{$\begin{array}{l}\text { Total fecal } \\
\text { collection }\end{array}$} & \multicolumn{2}{|c|}{$\begin{array}{c}\text { Ash-free indigestible acid } \\
\text { detergent fiber-extraction } \\
\text { method }^{\mathrm{a}}\end{array}$} & \\
\hline & & 12 & 3 & $\mathbf{S E}^{b}$ \\
\hline
\end{tabular}

Ash-free

Indigestible acid

detergent fiber, $\%^{\text {cd }}$

feed organic matter

$\mathrm{CV}^{\mathrm{e}}$

$\begin{array}{rrr}12.2 & 14.8 & 15.2 \\ -\quad 5.4 & 9.0 & 6.4\end{array}$

.5

Fecal recovery of ash-free indigestible

acid detergent fiber, $\%^{f}$

Forage organic matter digestibility, $\%^{\text {deh }}$

$\begin{array}{llllll}64.6 & 63.1 & 54.0 & 55.4 & 2.2\end{array}$

- Methods analytically defined as ash-free acid detergent fiber remaining after (i) Tilley and Terry (1963) in vitro dry matter disappearance, then $96 \mathrm{~h}$ in vitro incubation; (2) $24 \mathrm{~h}$ digestion in $\mathrm{HCl} /$ pepsin, then $96 \mathrm{~h}$ in vitro incubation and (3) $96 \mathrm{~b}$ in vitro incubation.

Standard error of the mean.

cMethod 1 vs Method $3(P<.0001)$

dMethod 1 vs Method $2(P<.01)$.

${ }^{\circ} \mathrm{CV}=\mathrm{Coefficient}$ of variation. Values are the mean within sample coefficient of yariation for duplicate determinations.

${ }^{1}$ Method 1 vs Method $3(P<.1)$.

Total collection vs Method $2(P<.01)$.

'Total collection vs Method $3(P<.01)$

ods of intense grazing to avoid fasting-induced selective grazing (Sidahmed et al. 1977). If esophageal masticate samples were contaminated with ruminal contents, they were discarded and another collection was made. Samples were frozen $\left(-40^{\circ} \mathrm{C}\right)$ after collection for later chemical analyses. Esophgeal samples were lyophilized, ground through a 1-mm screen in a Wiley Mill, and were composited $(w / w)$ within wether and period.

At the end of each collection period, pasture samples were collected at 5 randomly selected $.9-\mathrm{m}^{2}$ areas by clipping at ground level and pasture dry matter yield estimated for the forage dry weight. Samples were ground through a 1 -m screen in a Wiley Mill and composited $(w / w)$ across areas within period.

Esophageal masticate samples were analyzed for CP, NDF, $A D F$, and IVOMD by methods described for the digestion trial. Ash content of esophageal masticate, pasture and fecal samples were determined by ignition at $600^{\circ} \mathrm{C}$ for 6 hours. Indigestible acid detergent fiber in esophageal, fecal and pasture samples were analytically defined as the ash-free ADF present after in vitro digestion using the Moore modification (Harris 1970) of Tilley and Terry (1963) followed by re-inoculation with ruminal fluid and McDougall's buffer (McDougall 1948) for a 96-hour incubation period (Method 1 and inoculum source used in wether digestion trial). In vitro organic matter indigestibility of esophageal masticate, pasture and fecal samples were determined as 100-IVOMD by methods described for the digestion trial. All values were expressed as a proportion of organic matter.

Indigestible acid detergent fiber and in vitro indigestibility of esophageal masticate and pasture samples were used to estimate OMD utilizing the marker-ratio technique (Harris 1970). The 4 equations used IADF of pasture sample, IADF of esophageal masticate, in vitro indigestibility of pasture and in vitro indigestibility of esophageal masticate for computation of digestibility of the grazed material.

The experimental design was a repeated measures design (Gill and Hafs 1971) with period and sheep in the main plot and method of digestibility determination and its interactions in the subplot. Main plot effects of period and sheep were tested with the period by sheep interaction as the error term. Subplot effects were tested using residual error. Comparison of methods arranged as a $2 \times 2$ factorial with main effects of sample (esophageal or pasture) and method of calculation (IADF or indigestibility of OM) was by the use of orthogonal contrasts. Contrasts were: pasture samples vs esophageal masticate, IADF vs indigestibility and IADF of pasture samples vs IADF of esophageal masticate (Steel and Torrie 1970).

Components of variance of fecal IADF content associated with wether, period of grazing, and day within period were calculated from the analysis of variance (Henderson 1969). The equation $\left.n_{2}=S_{2}^{2} /\left[n_{1} \times R^{2}\right) / 4-S_{1}^{2}\right]$ where $n_{2}=$ number of samples for a specific number of animals $\left(n_{1}\right), S_{2}^{2}=$ estimated component of variance for daily samples, $S_{1}^{2}=$ estimated component of variance for animals and $R$ = range in fecal IADF content, was used to calculate the number of fecal grab samples needed to estimate fecal IADF content (Snedecor and Cochran 1967).

\section{Results and Discussion}

\section{Wether Digestion Trial}

The major objective of this trial was to identify the most promising procedures to extract IADF from a forage across 4 stages of maturity. This trial was conducted with wilted forages in an experimental design with good control on variation.

Table 2. Effects of extraction method on indigestible acid detergent fiber content in feed, fecal recovery and organic matter digestibility measured by total fecal collection and feed:feces ratio-steers.

\begin{tabular}{|c|c|c|c|c|c|c|c|c|}
\hline \multirow[b]{4}{*}{ Item } & \multirow{4}{*}{$\begin{array}{l}\text { Total fecal } \\
\text { collection }\end{array}$} & \multicolumn{6}{|c|}{ Ash-free indigestible acid detergent fiber extraction method ${ }^{\mathrm{a}}$} & \multirow[b]{4}{*}{$\mathbf{S E}^{\mathbf{b}}$} \\
\hline & & & & & & & & \\
\hline & & \multicolumn{2}{|c|}{ Endpoint, hours } & \multicolumn{2}{|c|}{ Endpoint, hours } & \multicolumn{2}{|c|}{ Endpoint, hours } & \\
\hline & & 96 & 120 & 96 & 120 & 96 & 120 & \\
\hline $\begin{array}{l}\text { Ash-free indigestible acid detergent } \\
\text { fiber, \% feed organic matter } \\
C^{\mathrm{d}} \\
\text { Fecal recovery of ash-free }\end{array}$ & - & $\begin{array}{r}17.8 \\
4.1\end{array}$ & $\begin{array}{r}17.2 \\
3.9\end{array}$ & $\begin{array}{r}18.0 \\
4.9\end{array}$ & $\begin{array}{r}16.9 \\
4.7\end{array}$ & $\begin{array}{r}19.3 \\
8.0\end{array}$ & $\begin{array}{r}19.6 \\
8.0\end{array}$ & .56 \\
\hline $\begin{array}{l}\text { indigestible acid detergent fiber, } \%^{\mathrm{c}} \\
\text { Forage organic matter }\end{array}$ & - & 102.4 & 111.0 & 100.1 & 113.0 & 91.9 & 87.3 & 4.70 \\
\hline digestibility & 56.5 & 56.1 & 58.9 & 54.1 & 59.4 & 47.9 & 48.3 & 2.35 \\
\hline
\end{tabular}

"Methods analytically defined as ash-free acid detergent fiber remaining after (1) Tilley and Terry (1963) in vitro dry matter disa ppearance, then $96 \mathrm{~h}$ in vitro incubation; (2) $24 \mathrm{~h}$ digestion in $\mathrm{HCl} /$ pepsin, then $96 \mathrm{~h}$ in vitro incubation and (3) $96 \mathrm{~h}$ in vitro incubation.

Standard error of the mean.

cMethod 1 vs Method $3(P<.01)$.

${ }^{\mathrm{d}} \mathrm{CV}=$ Coefficient of variation. Values are the mean within sample coefficient of variation for duplicate determinations.

Total collection vs Method $3(P<.01)$ 
Intermediate wheatgrass hay $\mathrm{CP}$ content decreased quadratically $(P<.05)$ from 10.5 to $3.8 \pm .2 \%$, NDF increased quadratically $(P<.1)$ from 70.1 to $72.9 \pm .7 \%$, ADF content increased quadratically $(P<.01)$ from 41.4 to $43.0 \pm .4 \%$ but ADL was not affected $(5.6 \pm .5 \%)$ as forage maturity increased. Forage $O M$ intake by wethers decreased linearly $(P<.01)$ from 973 to $447 \pm 56 \mathrm{~g} / \mathrm{d}$ across forage maturity. Fecal IADF, on an organic matter basis, linearly increased $(P<.01)$ across forage maturity and averaged $30.9,32.6$, 34.5 , and $35.0 \pm .35 \%$ for wethers fed maturity $1,2,3$, and 4 , respectively.

Methods of ash-free IADF extraction and recovery of IADF in feces (Table 1) were not affected $(P>.1)$ by intermediate wheatgrass maturity, and an intermediate wheatgrass maturity by extraction method interaction was not detected ( $P>.1$, data not shown). Therefore, forage maturity or digestibility did not affect fecal recovery of IADF. Possibly, differences in IADF extraction procedures between our study and Penning and Johnson (1983) and Cochran et al. (1986) contributed to differences in fecal recovery of IADF across studies.

Intermediate wheatgrass hay IADF content averaged 12.2, 14.8, and $15.2 \%$ for extraction Methods 1, 2, and 3, respectively (Table 1). Method 1 differed $(P<.01)$ from Methods 2 and 3. Additionally, the larger coefficients of variation for duplicate analyses by Methods 2 and 3 indicated that a greater number of samples would be needed to estimate IADF content precisely by those methods than by Method 1 . Fecal IADF recovery averaged $96.9,80.6$, and 77.2\% for Methods 1, 2, and 3, respectively. Method 1 differed from Method $3(P<.1)$. Previously, IADF recovery (extracted by Method 1) approached $100 \%$ in steers fed a cornstalk-based diet (K.C. Dehaan and T.J. Klopfenstein, unpublished data). Estimates of OM digestibility that used IADF extraction Method $r$ in feed to feces ratio did not differ $(\boldsymbol{P}>.5)$ from total fecal collection. However, total fecal collection OM digestibility differed $(P<.01)$ from those calculated from feed to feces ratio that used IADF extraction Methods 2 or 3. These data indicated that IADF extraction Method 1 did not overestimate the IADF content of feed as suggested by Cochran et al. (1986) or of feces as suggested by Penning and Johnson (1983). Cochran et al. (1986) and Penning and Johnson (1983) noted this overestimation of IADF content when forages with more than $80 \%$ in vivo dry matter digestibility were fed. However, IADF extraction methods used by Cochran et al. (1986) and Penning and Johnson (1983) differed from methods used in the current study. Cochran et al. (1986) used a procedure similar to Method 3 in the current study except that a 120-hour incubation was used instead of a 96-hour incubation. Penning and Johnson (1983) used a 240-hour incubation in cellulase to isolate IADF. Cochran et al. (1986) also noted significant differences between OMD determined by total fecal collection and that calculated by marker ratio using cellulase insoluble ADF. However, they noted that OMD calculated using the marker ratio of IADF did not differ from total collection. Therefore, methodological differences in IADF extraction, across studies, apparently affect the extent of an in vitro ADF disappearance and(or) fecal ADF recovery.

\section{Steer Digestion Trial}

The major objective of this trial was to compare the IADF extraction procedures used in Trial 1 , across maturity of a forage, fed fresh not wilted, in an experimental design commonly used in grazing studies. Additionally, we questioned whether a 120-hour in vitro incubation would increase fecal recovery of IADF extracted by Methods 2 and 3.

Composition of forage fed to steers decreased in CP content from 14.2 to $9.1 \%$ and IVOMD from 69.1 to $42.6 \%$ and increased in NDF, ADF, and ADL content with forage maturity. Forage organic matter intake decreased quadratically $(R<.0001)$ with forage maturity and averaged $6.4,9.4,8.8,9.1,8.5$, and $7.7 \pm .3 \mathrm{~kg} / \mathrm{d}$ for maturity $1,2,3,4,5$, and 6 , respectively. Fecal IADF content quadratically increased $(P<.001)$ with bromegrass maturity and averaged $36.7,34.1,42.6,42.9,38.6$, and $36.5 \pm 1.1 \%$ for maturity $1,2,3,4,5$, and 6 , respectively.

No IADF extraction method by endpoint, bromegrass maturity by endpoint, or bromegrass maturity by method interaction was detected for feed IADF content. Quantity of IADF extracted from fresh forage (Table 2) differed among methods. In contrast to trial 1 , Method 1 differed $(P<.01)$ from Method 3 but not Method 2. No main effect of endpoint was detected. These data indicate that extent of ADF disappearance has been reached with a 96-hour in vitro incubation and that IADF content of fresh forage could be extracted by either Method 1 or 2.

Similar to results of the wether digestion trial, the larger coefficient of variation for IADF extraction by Method 3 indicated that a greater number of samples would be needed to estimate IADF content precisely by Method 3 than Method 1 (Table 2). Fecal recovery of IADF only differed $((P<.01)$ between Methods 1 and 3. Forage $\mathrm{OM}$ digestibility determined by total collection differed $(P<.01)$ from $O M$ digestibility calculated from feed to feces ratio of IADF extracted by Method 3 but not Methods 1 or 2 .

Results of this trial support the conclusions from the wether digestion trial except that OM digestibility calculated using IADF extracted from fresh forage by Method 2 did not differ from $O M$ digestibility measured by total collection. Possibly, differences in wilting, hydration, and/or sample preparation affected the in vitro rate and extent of ADF disappearance. Therefore, use of Method 1 or 2 to extract IADF from fresh forage may be acceptable.

\section{Wether Grazing Trial}

This grazing trial was designed to determine variability of fecal IADF content, and to estimate the number of fecal grab samples needed to estimate fecal IADF content, of free grazing wethers. An additional objective was to compare $O M$ digestibility estimates calculated from feed to feces ratio of IADF with those calculated using in vitro indigestibility. Because the previous trials indicated the value of IADF as an internal marker, we questioned if indigestible $O M$ would yield comparable $O M$ digestibility estimates to IADF. Extraction of indigestible OM residues with acid detergent solution should remove most of the indigestible endogenous fecal residues but if endogenous fecal excretion is small and does not vary among animals and periods, estimation of $O M$ digestibility by either internal marker may be acceptable.

Forage standing crop declined from 2,197 to $616 \mathrm{~kg} / \mathrm{ha}$ from the beginning to the end of the trial. Standing crop IADF contents were $14.4,17.4,23.4$, and $20.4 \%$ for periods $1,2,3$, and 4 , respectively. Standing crop in vitro organic matter digestibilities were $61.9,51.7,52.1$, and $46.3 \%$ for periods $1,2,3$, and 4 , respectively. Esophgeal masticate CP, NDF, ADF, and IADF were cubically

Table 3. Chemical composition of esophageal masticate organic matter from graxing weathers".

\begin{tabular}{lccccc}
\hline & \multicolumn{5}{c}{ Item $^{\mathrm{b}}$} \\
\cline { 2 - 6 } Period & $\mathrm{CP}^{\mathrm{c}}$ & $\mathrm{NDF}^{\mathrm{c}}$ & ADF $^{\mathrm{c}}$ & IVOMD & IADF \\
\hline & & & & & \\
& 19.1 & 62.0 & 39.6 & 69.9 & 8.6 \\
2 & 14.4 & 68.6 & 40.7 & 67.4 & 11.0 \\
3 & 17.6 & 64.0 & 39.8 & 62.4 & 8.2 \\
4 & 15.3 & 65.4 & 43.2 & 54.6 & 12.2 \\
$\mathrm{SE}^{\mathrm{d}}$ & 1.10 & 2.41 & 1.82 & 5.13 & 1.11 \\
\hline
\end{tabular}

"Mean of four animals per period.

${ }^{b} \mathrm{CP}=$ crude protein, $\mathrm{NDF}$ = neutral detergent fiber, $\mathrm{ADF}$ = acid detergent fiber; IVOMD = in vitro organic matter digestibility; $I A D F=$ indigestible acid detergent fiber; $O M=$ organic matter.

${ }^{c}$ Cubic effect of period $(P<.05)$.

${ }^{\mathrm{d}} \mathrm{Standard}$ error of the mean. 
Table 4. Effect of sampling period and day within period on ash-free indigestible acid detergent fiber content of feces from grazing wethers.

Day within Period

\begin{tabular}{|c|c|c|c|c|c|}
\hline Period & 1 & 2 & 3 & 4 & 5 \\
\hline & - & - -IA & $\%$ fecal & $x$ & \\
\hline 1 & 32.2 & 32.1 & 32.1 & 31.6 & 29.7 \\
\hline 2 & 32.6 & 31.7 & 31.7 & 31.8 & 33.5 \\
\hline 3 & 34.1 & 34.0 & 33.6 & 33.0 & 35.0 \\
\hline 4 & 35.6 & 37.0 & 35.9 & 35.4 & 34.1 \\
\hline
\end{tabular}

IADF = Ash-free indigestible acid detergent fiber; $O M=$ organic matter. 'Standard error of the mean was .63 .

'Period by day interaction $(P<.05)$.

affected by period of grazing (Table 3).

A grazing period by sampling day interaction was detected $(P<.05)$ for fecal IADF content (Table 4). However, day within period was not a significant effect in the model so apparently this interaction was the result of small changes in fecal IADF content. Components of variance associated with wether, period and day of sampling for fecal IADF content (Table 5) calculated from the analysis of variance were small for wether and day of sampling, which precluded estimation of number of samples required to estimate fecal IADF content.

Table 5. Components of variance for fecal indigestible acid detergent fiber content of graxing wethers.

\begin{tabular}{lccc}
\hline \hline $\begin{array}{l}\text { Source of } \\
\text { variation }\end{array}$ & d.f. & $\begin{array}{c}\text { Mean } \\
\text { square }\end{array}$ & $\begin{array}{c}\text { Component of } \\
\text { variance }\end{array}$ \\
\hline Wether & 3 & 22.90 & 0.58 \\
Period & 3 & 65.43 & 2.67 \\
Day & 4 & 1.66 & -0.24 \\
\hline
\end{tabular}

A period by method interaction was detected $(P<.05)$ for $\mathrm{OM}$ digestibility (Table 6). Using IADF content of pasture samples underestimated, relative to the other methods, OM digestibility. Certainly, selective grazing by the wethers resulted in standing crop estimates not accurately estimating composition of intake. The period by IADF method interaction appeared to be due to change in relative order of the methods in periods 2 and 3. Comparison of esophgeal masticate IVOMD (Table 3 ) with OM digestibility calculated using esophageal masticate to feces ratio of IADF or in vitro indigestibility of $\mathrm{OM}$ (Table 6) indicated both over and under estimates across period of grazing. Digestibility of OM calculated

Table 6. Organic matter digestibility by graxing wethers estimated with feed to feces ratios of either ash-free indigestible acid detergent fiber or in vitro organic matter indigestibillty using esophageal and clipped (standing crop) fornge samples.

\begin{tabular}{|c|c|c|c|c|}
\hline \multirow[b]{2}{*}{ Period } & \multicolumn{4}{|c|}{ Method" } \\
\hline & $\begin{array}{c}\text { IADF } \\
\text { of standing } \\
\text { crop OM }\end{array}$ & $\begin{array}{c}\text { IADF of } \\
\text { esophageal } \\
\text { masticate OM }\end{array}$ & $\begin{array}{l}\text { In vitro } \\
\text { indigestibility } \\
\text { of standing } \\
\text { crop OM }\end{array}$ & $\begin{array}{c}\text { In vitro } \\
\text { indigestibility } \\
\text { of esophageal } \\
\text { masticate OM }\end{array}$ \\
\hline & \multicolumn{4}{|c|}{$\ldots \ldots \ldots$ OM digestibility ${ }^{b c} \ldots \ldots \ldots$} \\
\hline 1 & 30.8 & 68.2 & 60.2 & 63.9 \\
\hline 2 & 39.2 & 61.2 & 54.6 & 64.8 \\
\hline 3 & 17.6 & 71.4 & 64.0 & 68.7 \\
\hline 4 & 24.6 & 53.6 & 55.8 & 62.6 \\
\hline
\end{tabular}

IADF = Ash-free indigestible acid detergent fiber.

Standard error of the mean was 3.1 .

${ }^{C}$ Period by method interaction $(P<.05)$. using esophageal masticate IADF in feed to feces ratio differed by $-1.7,-6.2,9.0$, and -1.0 percentage-units from esophageal masticate IVOMD for period $1,2,3$, and 4 , respectively, whereas, digestibility of $\mathrm{OM}$ calculated using esophageal masticate indigestible $O M$ in feed to feces ratio differed by $-6.0,-2.6,6.3$, and 8.0 percentage-units from esophagcal masticate IVOMD for period 1 , 2, 3, and 4, respectively. However, using IADF of esophageal masticate to calculate $O M$ digestibility resulted in average values across period closer to esophageal masticate IVOMD than the other methods. Possibly, changes in rate of passage and(or) endogenous fecal excretion of OM contributed to differences between internal marker performance and differences between esophageal masticate IVOMD and OM digestibility calculated from feed to feces ratios.

In summary, these experiments show that appropriate methods of IADF extraction from feed must be used for IADF to be a suitable internal marker. Further, because fecal IADF content from grazing wethers varied little across 5 days within a period, it appeared that small changes in feed IADF content could have major effects on calculated digestibility. Ash-free IADF extracted from feed by Method 1 appeared to be a suitable internal marker to calculate digestibility for forage fed or grazing ruminants consuming forage of 58 to $70 \%$ organic matter digestibility. However, Method 2 may be appropriate for feed samples that were not dried before IADF extraction. Further research would be needed to determine the value of Method 2 over a range of forages and experimental conditions.

\section{Literature Cited}

AOAC. 1980. Official methods of analysis (14th Ed.). Assoc. Official Analytical Chemists, Washington, DC.

Berger, L., T. Klopfenstein, and R. Britton. 1979. Effect of sodium hydroxide on efficiency of rumen digestion. J. Anim. Sci. 49:1317-1323.

Cochran, R.C., D.C. Adams, J.D. Wallace, and M.L. Galyean. 1986. Predicting digestibility of different diets with internal markers: Evaluating four potential markers. J. Anim. Sci. 63:1476-1483.

Ellis, W.C., E.M. Bailey, and C.A. Taylor. 1984. A silicone esophageal cannula; its surgical installation and use in research with grazing cattle sheep or goats. J. Anim. Sci. 59:204-209.

Fahey, G.C., and H.G. Jung. 1983. Lignin as a marker in digestion studies: A review. J. Anim. Sci. 57:220-225.

Faichney, G.J. 1975. The use of markers to partition digestion within the gastrointestinal tract of ruminants. p. 277-291. In: I.W. MacDonald and A.C.I. Warners (Eds) Digestion and Metabolism in the Ruminant. Univ. of New England Publishing Unit, NSW, Australia.

Gill, J.S., and H.D. Hafs. 1971. Analysis of repeated measurements of animals. J. Anim. Sci. 33:331-336.

Goering, H.K., and P.J. Van Soest. 1970. Forage fiber analyses: Apparatus, reagents, procedures and some application. Agr. Handb. 379, USDA, ARS, Washington, DC.

Harris, L.E. 1970. Nutrition research techniques for domestic and wild animals. L.E. Harris, 1408 Highland Drive, Logan, Utah.

Henderson, C.R. 1969. Design and analysis of animal science experiments. Techniques and procedures in animal science research. Amer. Soc. Anim. Sci. c/o Q Corp., Albany, N.Y.

Hunt, C.W., J.A. Paterson, S.J. Miller, and J.E. Williams. 1984. Comparison of several internal and external markers for estimating dry matter digestibility and fecal output by steers. J. Anim. Sci. (Suppl. 1):427 (Abstr.).

Kotb, A.R., and T.D. Luckey. 1972. Markers in nutrition. Nutr. Abstr. Rev. 42:813-845.

McDougall, E.I. 1948. Studies on ruminant saliva. 1. Composition and output of sheep's saliva. Biochem. J. 43:99-109.

Mertens, D.R. 1976. Dietary fibre components: Relationships to the rate and extent of ruminal digestion. Fed. Proc. 36:187-192.

Nelson, M.L., T.J. Klopfenstein, R.A. Britton, and S.R. Lowry. 1985. Protein supplementation of ammoniated roughages. III. Corncobs supplemented with a blood meal-corn gluten meal mixture--steer studies. J. Anim. Sci. 61:1567-1575. 
Penning, P.D., and R.H. Johnson. 1983. The use of internal markers to estimate herbage digestibility and intake. 2. Indigestible acid detergent fibre. J. Agr. Sci. (Camb.) 100:133-138.

Seales, G.H., G.L. Streeter, A.H. Denham, and G.M. Ward. 1974. A comparison of indirect methods of predicting in vivo digestibility of grazed forage. J. Anim. Sci. 38:192-199.

Schneider, B.H. and W.P. Flatt. 1975. The evaluation of feeding through digestibility experiments. p. 169 Univ. Georgia Press, Athens.

Sidahmed, A.E., J.E. Morris, W.C. Weir, and D.T. Torrell. 1977. Effect of the length of fasting on intake, in vitro digestibility and chemical composition of forage samples collected by esophageal fistulated sheep. $J$. Anim. Sci. 45:885-890.
Snedecor, G.W., and W.G. Cochran. Statistical methods (6th Ed.). The lowa State Univ. Press, Ames.

Steel, R.D.G., and J.H. Torrie. 1980. Principles and procedures of statisties. (2nd Fd.) McGraw-Hill Book Co., Inc. New York.

Streeter, C.L. 1969. A review of techniques used to estimate the in vivo digestibility of grazed forage. J. Anim. Sci. 29:757-768.

Tilley, J.M.A., and R.A. Terry. 1963. A two-stage technique for the in vitro digestion of forage crops. J. Brit. Grassl. Soc. 18:104-111.

Waller, J., N. Merchen, T. Hanson, and T. Klopfenstein. 1980. Effects of sampling intervals and digesta markers on abomasal flow determinations. J. Anim. Sci. 50:1122-1126. 